\title{
Study of altitude of first year medical students towards teaching and learning embryology
}

\author{
Renuka S Ahankari ${ }^{*}$, Sudhir M Sant ${ }^{2}$ \\ ${ }^{1}$ Associate Professor, ${ }^{2}$ Professor and HOD, Department of Anatomy, Shrimati Kashibai Navale Medical College and General Hospital, Narhe, \\ Pune-411041, Maharashtra, INDIA. \\ Email: adgaonkarrenuka36@gmail.com
}

Abstract Objectives: To take feedback from $1^{\text {st }}$ M.B.B.S. Students regarding difficulty in learning Embryology and to address their contemporary learning needs in view of improving their performance, at Department of Anatomy, Shrimati Kashibai Navale Medical college and General Hospital, Pune, Maharashtra, with the help of a specially designed questionnaire. Materials and Method: Input from the students were collected from the 150 MBBS students of 2016-17 batch who completed first year MBBS. It was done by using a specially designed questionnaire comprising of points relating to the curriculum, teaching methodology in Embryology used at Department of Anatomy, Shrimati Kashibai Navale Medical college and General Hospital, Pune. Results: Majority of the students found studying embryology easier although there was a higher percentage of students who kept the subject optional In view of the students, best source of study material was lecture followed by textbooks. The Email information about embryology models was found beneficial by most of the students especially for revision Increasing the number of lectures, number of practical demonstrations, using more visual aids including 3 D videos,, revision lectures at the end of curriculum Part completion test for Embryology, addition of Seminars and Multiple choice question-Answer sessions to routine teaching were few of the suggestions given by the students. Conclusion: According to the students, including multimedia technology along with the lectures will be most beneficial for understanding the subject which will also improve their performance in the exam and in future will definitely help for better diagnosis of congenital anomalies.

Key Words: Embryology learning, Students feedback, Questionnaire,Teaching Method, 3 D videos.

*Address for Correspondence:

Dr. Renuka S. Ahankari, Associate Professor, Department of Anatomy, Shrimati Kashibai Navale Medical college and General Hospital,

Narhe, Pune-411041, Maharashtra, INDIA.

Email: adgaonkarrenuka36@gmail.com

Received Date: 02/07/2018 Revised Date: 20/08/2018 Accepted Date: 14/09/2018

DOI: https://doi.org/10.26611/1001731

\begin{tabular}{|l|l|}
\hline \multicolumn{2}{|c|}{ Access this article online } \\
\hline Quick Response Code: & Website: \\
\hline & www.medpulse.in \\
\hline
\end{tabular}

\section{INTRODUCTION}

Training physicians to be effective practitioners throughout their careers begins in undergraduate medical education with particular focus on self-directed inquiry, professional and Inter professional development, and competency-based assessment ${ }^{1}$. Anatomy is one of the fundamental sciences in the medical curriculum.
Physicians with a thorough knowledge of anatomy limit the use of expensive technique of diagnosis ${ }^{6}$. Embryology, which deals with the normal development of human being, is one of the important aspects of Anatomy. Knowledge of normal and abnormal human development is important for understanding the pathophysiology, clinical treatment and surgical repair of malformations ${ }^{11}$. The interest in teaching embryology in a medical course is justified by the fact that birth defects are the leading cause of infant mortality with a prevalence of up to $15 \%$ that can account for approximately $21 \%$ of infant deaths ${ }^{11}$. The reduction in duration of the $1^{\text {st }}$ M.B.B.S. course has motivated many medical teachers to seek novel teaching methods for optimium utilisation of the available time for students learning. ${ }^{7}$ he teaching must be done in a way that allows the students to learn effectively ${ }^{4}$ and so we decided to take a feedback from $\mathrm{I}^{\text {st }}$ M.B.B.S. Students to know their opinion regarding their perspective towards the study of embryology and how 
they feel about present teaching methods (which included both theory as well as practical). The poor performance of the students in domain of Embryology also triggered us to take their feedback which was taken with the help of a well constructed and validated questionnaire. The students were also asked about their suggestions in order to improve the present teaching methods which in turn would help to develop their interest in the subject.

\section{MATERIAL AND METHODS}

During the academic year (2016-2017), the lectures on embryology were conducted for 150 students of Ist M.B.B.S. At the end of each system the models were shown to the students in a batch of 30 throughout the academic year. Labelled photographs of embryology models were sent after the end of each topic or system to the students via email so that they can revise it as per their convenience. The teaching of gross anatomy and embryology was co-related. At the end of the academic year (2016-2017), all the students s of $1^{\text {st }}$ M.B.B.S. were given a specially designed questionnaire which was validated by the subject expert. It included 10 questions comprising of points related to the teaching methodology used for embryology. Their feedback was analysed and results were drawn from the analysis.

\section{OBSERVATIONS}

Question wise analysis of our study is tabulated below.

Q.1. Do you keep Study of Embryology as last option?

A. Yes B. No

Table 1:

\begin{tabular}{|c|c|c|c|c|c|c|c|c|}
\hline $\begin{array}{l}\text { Question } \\
\text {-No. }\end{array}$ & $\begin{array}{c}\text { Total No. } \\
\text { Of Students }\end{array}$ & \multicolumn{2}{|c|}{$\begin{array}{l}\text { No. Of Students } \\
\text { For each Option }\end{array}$} & & \multicolumn{3}{|c|}{$\begin{array}{l}\text { \% age Of Students } \\
\text { For each Option }\end{array}$} & Any other remark \\
\hline 1 & 150 & $\begin{array}{c}\text { A } \\
100\end{array}$ & $\begin{array}{c}B \\
49\end{array}$ & $\begin{array}{c}\text { NA } \\
1\end{array}$ & $\begin{array}{c}A \\
66.66\end{array}$ & $\begin{array}{c}B \\
32.66\end{array}$ & $\begin{array}{l}\text { NA } \\
0.66\end{array}$ & \\
\hline
\end{tabular}

Q.2. Is Embryology Easier or Difficult than Gross Anatomy to understand?

A. Easier B. Difficult C. Equal

\begin{tabular}{|c|c|c|c|c|c|c|c|c|c|c|}
\hline $\begin{array}{l}\text { Que. } \\
\text { No. }\end{array}$ & $\begin{array}{l}\text { Total No. Of } \\
\text { Students }\end{array}$ & & $\begin{array}{l}0 \\
\text { rea }\end{array}$ & & & & $\begin{array}{l}\text { ige C } \\
\text { r ea }\end{array}$ & $\begin{array}{l}\text { dents } \\
\text { tion }\end{array}$ & & $\begin{array}{l}\text { Any other } \\
\text { remark }\end{array}$ \\
\hline 2. & 150 & $\begin{array}{l}A \\
68\end{array}$ & $\begin{array}{c}B \\
33\end{array}$ & $\begin{array}{l}C \\
49\end{array}$ & $\begin{array}{c}\text { NA } \\
0\end{array}$ & $\begin{array}{c}\text { A } \\
45.33\end{array}$ & $\begin{array}{c}B \\
22\end{array}$ & $\begin{array}{c}C \\
32.66\end{array}$ & $\begin{array}{c}\text { NA } \\
0\end{array}$ & \\
\hline
\end{tabular}

Q.3. Do you think study of Embryology helps to understand Gross Anatomy better?

A. Yes B. No C. Not sure

Table 3:

\begin{tabular}{|c|c|c|c|c|c|c|c|c|c|c|}
\hline $\begin{array}{l}\text { Que. } \\
\text { No. }\end{array}$ & $\begin{array}{l}\text { Total No. Of } \\
\text { Students }\end{array}$ & & $\begin{array}{l}\text { No. Of } \\
\text { For ea }\end{array}$ & & & & $\begin{array}{l}\text { age Of } \\
\text { or eac }\end{array}$ & $\begin{array}{l}\text { lents } \\
\text { tion }\end{array}$ & & $\begin{array}{c}\text { Any other } \\
\text { remark }\end{array}$ \\
\hline 3 & 150 & $\begin{array}{c}\mathrm{A} \\
121\end{array}$ & $\begin{array}{c}\text { B } \\
13\end{array}$ & $\begin{array}{c}C \\
16\end{array}$ & $\begin{array}{c}\text { NA } \\
0\end{array}$ & $\begin{array}{c}A \\
80.66\end{array}$ & $\begin{array}{c}B \\
8.66\end{array}$ & $\begin{array}{c}C \\
10.66\end{array}$ & $\begin{array}{c}\text { NA } \\
0\end{array}$ & \\
\hline
\end{tabular}

Q. 4. Arrange the following factors which facilitate your learning of embryology as per their priority - Maximum beneficial to minimum beneficial.

A. Lectures B. Books C. Practical demonstration of embryology models D. Email information about the embryology models Maximun beneficial response chosen by students out of 150

\begin{tabular}{cccccc}
\multicolumn{7}{c}{ Table 4: } \\
\hline Option chosen & A & B & C & D & NA \\
\hline No. of students per option & 92 & 7 & 36 & 12 & 3 \\
\% of students per option & 61.33 & 4.66 & 24 & 8 & 1.39 \\
\hline
\end{tabular}

Q.5. Does simultaneous teaching of gross anatomy and embryology helps you in better understanding of the Subject? A. Yes B. No C. To some extent.

\begin{tabular}{|c|c|c|c|c|c|c|c|c|c|c|}
\hline $\begin{array}{l}\text { Que. } \\
\text { No. }\end{array}$ & $\begin{array}{l}\text { Total No. Of } \\
\text { Students }\end{array}$ & & $\begin{array}{l}.01 \\
\text { rea }\end{array}$ & & & & $\begin{array}{l}\text { ge } \\
\text { rea }\end{array}$ & $\begin{array}{l}\text { dents } \\
\text { tion }\end{array}$ & & $\begin{array}{l}\text { Any other } \\
\text { remark }\end{array}$ \\
\hline 5. & 150 & $\begin{array}{c}A \\
116\end{array}$ & $\begin{array}{l}B \\
3\end{array}$ & $\begin{array}{c}C \\
31\end{array}$ & $\begin{array}{c}\text { NA } \\
0\end{array}$ & $\begin{array}{c}\text { A } \\
77.33\end{array}$ & $\begin{array}{l}B \\
2\end{array}$ & $\begin{array}{c}C \\
20.66\end{array}$ & $\begin{array}{c}\text { NA } \\
0\end{array}$ & \\
\hline
\end{tabular}


Q.6 How many times each embryology model of each system should be demonstrated in the total duration of $1^{\text {st }}$ M.B.B.S.? A. Once B. twice C. Thrice

\begin{tabular}{|c|c|c|c|c|c|c|c|c|c|c|}
\hline $\begin{array}{l}\text { Que. } \\
\text { No. }\end{array}$ & $\begin{array}{l}\text { Total No. Of } \\
\text { Students }\end{array}$ & & $\begin{array}{l}\text { No. Of } \\
\text { For ea }\end{array}$ & & & & $\begin{array}{l}\text { age Of } \\
\text { or eac }\end{array}$ & $\begin{array}{l}\text { lents } \\
\text { tion }\end{array}$ & & $\begin{array}{l}\text { Any other } \\
\text { remark }\end{array}$ \\
\hline 6. & 150 & $\begin{array}{c}\text { A } \\
14\end{array}$ & $\begin{array}{c}\text { B } \\
74\end{array}$ & $\begin{array}{c}C \\
62\end{array}$ & $\begin{array}{c}\text { NA } \\
0\end{array}$ & $\begin{array}{c}A \\
9.33\end{array}$ & $\begin{array}{c}B \\
49.33\end{array}$ & $\begin{array}{c}\mathrm{C} \\
41.33\end{array}$ & $\begin{array}{c}\text { NA } \\
0\end{array}$ & \\
\hline
\end{tabular}

Q.7. How often do you see the photographs of labelled embryology models sent to you via Email? A. Once B. Twice C. More than twice.

\begin{tabular}{cccccccccc}
\hline $\begin{array}{c}\text { Que. } \\
\text { No. }\end{array}$ & $\begin{array}{c}\text { Total No. Of } \\
\text { Students }\end{array}$ & \multicolumn{3}{c}{$\begin{array}{c}\text { No. Of Students } \\
\text { For each Option }\end{array}$} & \multicolumn{3}{c}{$\begin{array}{c}\text { \% age Of Students } \\
\text { For each Option }\end{array}$} & $\begin{array}{c}\text { Any other } \\
\text { remark }\end{array}$ \\
\hline 7. & 150 & A & B & C & NA & A & B & C & NA \\
\end{tabular}

Q.8 Is the above mentioned information (mentioned in question no.7) helpful for revision? A. Yes B. No C. To some extent

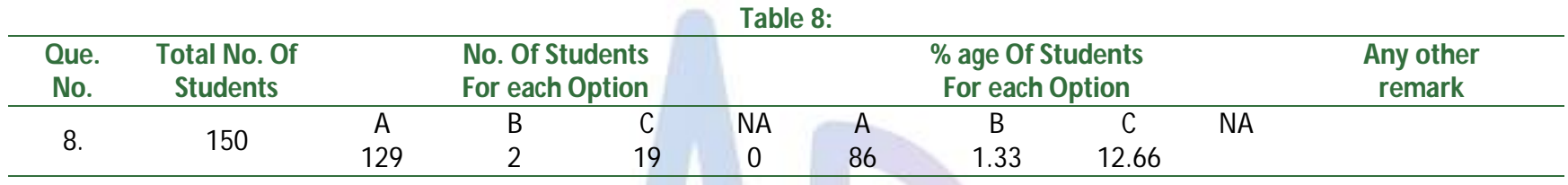

Q. 9. Do you think 3 Dimensional images and video clips should be added with conventional teaching of Embryology? A. Yes B. No C. Not sure

\begin{tabular}{ccccccccccc}
\hline $\begin{array}{c}\text { Que. } \\
\text { No. }\end{array}$ & $\begin{array}{c}\text { Total No. Of } \\
\text { Students }\end{array}$ & \multicolumn{3}{c}{$\begin{array}{c}\text { No. Of Students } \\
\text { For each Option }\end{array}$} & \multicolumn{3}{c}{$\begin{array}{c}\text { \% age Of Students } \\
\text { For each Option }\end{array}$} & $\begin{array}{c}\text { Any other } \\
\text { remark }\end{array}$ \\
\hline 9. & 150 & A & B & C & NA & A & B & C & NA & \\
& & 145 & 3 & 2 & 0 & 96.66 & 2 & 1.33 & 0 \\
\hline
\end{tabular}

Q. 10 In question no.10 we had asked the students to come up with new suggestions that will help in better understanding of embryology. Majority of the students $58 \%$ (87/150) were happy with the way of teaching and did not give any suggestion. However few students $1.33 \%$ $(2 / 150)$ wanted to make the subject more interesting and more exposure to embryology was demanded by very few $0.66 \%$ (1/150) student. Few students $11.33 \%$ (17/150) stressed on increasing the frequency of revisions while few $2 \%(3 / 150)$ wished that the portion should be finished faster so as to get time for self-study. As far as lectures were concerned, slow teaching1.33\% (2/150), increasing number of lectures $3.33 \%(5 / 150)$, taking lectures in batches $0.66 \%$ (1/150), giving more time for the topic $0.66 \%(1 / 150)$ were the suggestions that we have received. Revision lectures at the end of curriculum $0.66 \%(1 / 150)$ and a separate lecture $0.66 \%(1 / 150)$ before examination in which important questions will be emphasized were another suggestions. Regarding demonstration of embryology models, few students $2 \%(3 / 150)$ suggested that number of demonstration classes should be increased, while increasing the time allotted for individual demonstration was an another suggestion $0.66 \%$ (1/150). Some students1.33\% (2/150) were of the opinion that the embryology model demonstration if done immediately after the theory class will be more beneficial. Few students suggested 3D visualisation of models will be more beneficial during the lecture $1.33 \%$ (2/150). Few students wanted all the models of embryology to be sent via email with more detailed information $1.33 \%(2 / 150)$. Few students $2.66 \%$ (4/150) suggested that there should be part completion or topic completion test separately for embryology. Addition of Seminars 0.66\% (1/150), Multiple Choice Questions (1/150), Demonstration of slides of developing embryo $0.66 \%(1 / 150)$ were also suggested by the students. While we have asked separately about the addition of video clips along with the teaching as a separate question (Q.no.8), few students $6.66 \%(10 / 150)$ stressed on the same point. Few students $0.66 \%$ (1/150) specifically told that videos of developing embryo should be shown stepwise and at the end of curriculum video of as complete development of embryo should be shown. As very few videos are available on social media like you tube and good videos are payable, it was also asked whether the institute could 
pay for these videos so that they could be added in the lecture $0.66 \%(1 / 150)$.

\section{SUMMARY OF SUGGESTIONS}

A. Regarding the lectures, these were suggestions given by the students-

- Increase number of Lectures,

- Give more time for the topic,

- Take lectures in batches,

- Revision lectures at the end of curriculum

b. Demonstrate Embryology Models immediately after each theory lecture.

c. Part completion test for Embryology,

d. Addition of Seminars,

e. Addition of Multiple choice question-Answer sessions

\section{DISCUSSION}

Majority (66.66\%) of the students kept study of embryology as last option. After discussion with the faculty members we came up with the following possible factors for the students' approach

- Less weightage of marks in university,

- Vastness of the subject

- Suggestions from their seniors

Understanding of Embryology as compared to Gross Anatomy was found easier by $45.33 \%$ students, difficult by $22 \%$ students, while $32.66 \%$ students opined that it was equal. This is in contrast to the results of studies done by Rashmi Jaiswalandetal ${ }^{9}$ and B Karmer and J T Soley ${ }^{3}$, wherein percentage of students unable to understand embryology was $42.63 \%$ and $64 \%$ respectively. However they have not compared embryology with gross anatomy. $80.66 \%$ students in our study think that study of Embryology helps to understand Gross Anatomy better, but $8.6 \%$ students do not agree with the above statement, where as $10.66 \%$ were not sure about it. Amongst the Lectures, Books, Practical demonstration of embryology models and Email information about the embryology models, $61.33 \%$ students opined that lectures were the best source of study material followed by Practical demonstration of embryology models and Email information about the embryology models (32\%) 77.33\% students agreed that parallel teaching of gross anatomy and embryology was helpful in better understanding of the subject, $20.66 \%$ said it was helpful to some extent and $2 \%$ did not find it helpful. The embryology models (of each system) were shown only once during the curriculum. But majority of the students have asked to demonstrate the models twice or thrice during the academic year (49.33\%). About $79 \%$ students refer to the email information frequently i.e.2/3 times, and $86 \%$ student found this information helpful particularly for revision. Renu Kumari, and et $a l^{10}$ during their questionnaire based study on Evaluating Anatomy Teaching Methodology concluded that majority of the students preferred the use of Power Presentations, visual aids like ( $3 \mathrm{D}$ models, videos) along with the use of chalk and board to simplify the concepts in gross anatomy, histology as well as embryology. Study done by Ghatak and $e t a l^{6}$ focused on use of digital visualizer for conduction of tutorials in Anatomy amongst first year undergraduate students as an alternative mode of innovative medical education technology as compared to conventional methods. They concluded that mean post test score of students was higher with the use of digital visualizer. Various studies have reported the educational effectiveness of $3 \mathrm{D}$ imensional models for teaching learning ${ }^{2,5,8}$. Kamkhedkar and et $a l^{7}$ in their study concluded that use of 3D Embryology models enable learning. Results of these studies coincide with our study where $96.6 \%$ of the students opined that use of $3 \mathrm{D}$ videos and $3 \mathrm{D}$ models should be a part of regular lecture. $7.3 \%$ students suggested that increasing number of lectures taking lectures in batches, using videos in lecture teaching, giving more time for the topic, revision lectures at the end of curriculum and a separate lecture before examination emphasizing upon important questions will definitely help them to score better marks. These suggestions were parallel to the study done by B Karmer and $\mathrm{J} \mathrm{T} \mathrm{Soley}{ }^{3}$ in which scheduling of more time and extra tutorials (11\%), use of more visual aids (10\%) and changing format of lectures by either converting them into small group tutorials and including physical specimen to demonstrate structural changes $(10 \%)$ were suggested as possible solutions towards learning problems in embryology.

\section{CONCLUSION}

Including multimedia technology during Lectures, increased time for the practical demonstrations of models, more number of part completion examinations, multiple choice questions are some important suggestions that we got from the students. The combined multifaceted approach of teaching will help to arouse more interest in a conceptual subject like Embryology and wil also help them in diagnosis of congenital anomalies.

\section{REFERENCES}

1. Aaron M. Yengo-Kahn, MD, Courtney E. Baker, and Kimberly D. Lomis, MD - Medical Students' Perspectives on Implementing Curriculum Change at One Institution Academic Medicine, April 2017; 92(4) pp455460 
2. Abid B, Hentati N, Chevallier JM, Ghorbel A, Delmas V, Douard R.-Traditional versus three dimensionalteachingof peritoneal embryogenesis: A comparative prospective study. Surgical Radiol Anat 2010; 32(7):647-652.

3. B Karmer and J T Soley.- Medical student perception on problems in Anatomy- East African medical journal. August 2002; 79(8):408-414.

4. Drake RL- Anatomy education in a changing medical curriculum. 1998 Anat.Rec. (New Anat.) 253.28-31.

5. Garcia LG Pacheco DA, de SousaRL, Santos RS, Brune FHR.EMBRIO-a 3D Software for Learning Embryology. IPEDR 2012; 41:73-78.

6. Ghatak S, Potaliya P, Pal R- Digital visualizer for teaching-learning in Anatomy. Journal of Research in Human Anatomy and Embryology 2016; Vol 2(2): JulyDecember2016; pp: 4-8.

7. Kamkhedkar Suchitkumar G, Malgaonkar Aniruddha Aand Kartikeyan S. - Three -Dimensionalembryology models as teaching aids for first year medical students.International Journal of Biomedical Research2017;08(04):177-181
8. Marsh KR, Giffin BF, LowrieJr.DJ. Medical student retentions of embryonic development: Impact of the dimensions added by multimedia tutorials. Anat Sci Educ 2008, 1(6):252-257.

9. Rashmi Jaiswal, Sameer Sathe, ivekanand Gajbhiye, Rashmi Sathe. - Students perception on methods of anatomy teaching and assessment. Int J Anat Res 2015; 3(2):1103-1108.

10. Renu Kumari, Amod KumarYadav, Bikramjeet Singh,Manpreet Kaur, Rimpi Gupta- Evaluating Anatomy Teaching Methodology As per tyr percipience of First year M.B.B.S. Students-A Questionaire Based Study International Journal of Basic and Applied Medical Sciences 2015, Vol 5(2): May- August ISSN 22772103(online) pp240-247

11. Suzana Guimaraes Moraes, Marta Vidigal de Andrade Reis, Marcos Fernando Santos Mello and Luis Antonio Violin Pereira-The usefulness of Autopsies as a tool for teaching

Embryology.Braz.J.mrphol.Sci.2004,21(3),117-123.

\section{Source of Support: None Declared}

Conflict of Interest: None Declared 